\title{
Environmental tastes, opinions and behaviors: social sciences in the service of cultural ecosystem service assessment
}

\author{
Tally Katz-Gerro $^{1}$ and Daniel E. Orenstein ${ }^{2}$
}

\begin{abstract}
Cultural ecosystem services are the nonmaterial ways in which humans derive benefits from ecosystems. They are distinct from other types of ecosystem services in that they are not only intangible, but they require an entirely different set of research tools to identify, characterize, and value them. We offer a novel way to assess how individuals perceive and use their local ecosystem, thereby advancing the state-of-the-art of cultural ecosystem service assessment. We identify distinct environmental "tastes" that represent general dispositions, preferences, or orientations regarding particular characteristics of the environment. We then use these environmental tastes to explain environmental behaviors (e.g., engagement in outdoor activities and resource conservation efforts) and opinions (e.g., perceived economic dependence on various environmental resources and opinions regarding environmentally focused development issues). We identify three distinct environmental tastes: "Landscape" is associated with the visual and sensory landscape; "Biota" is associated with living elements of the environment; and "Desert" is associated with the extreme climatic characteristics of the environment. We report that the "Biota" environmental taste has wide-ranging impact on subsequent measures of pro-environmental behaviors and opinions. We maintain that this taste dimension is important for the ability of researchers, land use managers, and policy-makers to understand and evaluate cultural ecosystem services and to characterize how humans perceive them and benefit from them.
\end{abstract}

Key Words: cultural ecosystem services; environmental attitudes and behaviors; environmental tastes; hyperarid ecosystems; socio-ecology

\section{INTRODUCTION}

Bringing the social sciences into ecosystem service assessment The concept of ecosystem services (ES) continues to proliferate into the research and policy-making communities as an organizing conceptual framework with which to characterize and emphasize the dependence of humans on natural ecosystems (e.g., de Groot et al. 2010, Costanza et al. 2014). Since its popularization by the 2005 Millennium Ecosystem Assessment (MA) (Reid et al. 2005), the terminology has been widely adopted by environmental and resource management communities. As the framework moved from the conceptual to the applied stage, it underwent refinement to enable empirical assessment (identification, characterization, and valuation) of ES. Terminology was refined as well, but precise and consistent definitions remain elusive. The definition of ES we adopted, provided by the UK National Ecosystem Assessment, is "the outputs of ecosystems from which people derive benefits" (UK-NEA 2011:12). Ecosystem services, by definition, thus provide measurable benefits for humans, valued in terms of human health, economic well-being, and/or socio-cultural meaning.

This research focuses on the third type of benefit- those outputs of ecosystems from which humans derive socio-cultural meaning. We introduce a novel approach for assessing how individuals perceive and use their local ecosystem, an approach that allows us to identify different groups according to their environmental "tastes." In order to demonstrate the relevance and implications of this new measure, we link these taste clusters to environmental opinions and behaviors. We suggest that this knowledge adds nuance to the important, but often poorly understood, concept of cultural ecosystem services (Daniel et al. 2012).
The ES concept, though originating within the ecological sciences (Ehrlich and Mooney 1983), is a distinctly anthropocentric concept - putting humans at the center of the ecological universe and measuring ecological health in terms of the system's ability to provide crucial benefits for human existence and well-being in the short and long term. Each of the four ES typologies defined by the MA (Reid et al. 2005) is anthropocentric: provisioning services that provide us food, shelter, water, and commercial goods; regulating services, which assure relatively stable biogeological cycles and climate in which humans have evolved and survive; cultural services, or those ecosystem outputs that provide humans with intangible benefits, including aesthetics, recreational opportunities, spiritual growth, community development, and education; and supporting services, which are the ecological processes that assure provision of all other services, thereby benefiting humans indirectly.

Assessing each type of service demands a particular disciplinary expertise or set of expertise. In the past, ecology and satellite disciplines contributed the most to ES assessment. The assessment of regulating and supporting services demands the particular expertise of natural scientists, and they are often the only people who are aware of the myriad ways in which human biological well-being is dependent on these services. At the same time, the natural sciences are less equipped than social science disciplines with theories and methodologies for assessing the socio-cultural value of ecosystems (Fagerholm et al. 2012). Economists have provided monetary valuation of ES, and they approached the topic equipped with experience and a diversity of valuation tools drawn from environmental economics (de Groot et al. 2002, Fisher et al. 2009). While acknowledging the

${ }^{1}$ Department of Sociology and Anthropology, University of Haifa, ${ }^{2}$ Faculty of Architecture and Town Planning, Technion - Israel Institute of Technology 
importance of socio-cultural benefits derived from ecosystems, it has also been acknowledged that economic tools have proved insufficient for assessing the value of such benefits (Balmford et al. 2011, Church et al. 2011, Daniel et al. 2012).

Thus, the valuation of cultural ES has proven to be a particular challenge because they elude monetization. The UK-NEA noted that "the MA's approach to cultural services struggled to find a consistent theoretical and methodological framework to match that underpinning other areas of the assessment" (Church et al. 2011:639). Since the predominant methods for valuating ES have been limited primarily to monetary measures, meanings and perceptions have been rendered a marginal aspect of ES assessment, and this has led to significant criticism of the entire ES assessment process (Kosoy and Corbera 2010, Spangenberg and Settele 2010, Dempsey and Robertson 2012, Luck et al. 2012). This criticism paralleled explicit calls to increase integration of social scientists, with their particular disciplinary skills, into interand transdisciplinary ES assessment (Duraiappah and Rogers 2011, Chan et al. 2012, Daniel et al. 2012, Raymond et al. 2013, Spangenberg et al. 2014). In their review of publications on cultural ecosystem services, Milcu et al. (2013) found few noneconomist social scientists engaged in the existing research on cultural ecosystem services.

In response to this lacuna, the budding literature focuses on how individuals use, perceive, and benefit from cultural ES (Bryan et al. 2010, Chan et al. 2012, Spangenberg et al. 2014). One of the first contributions of this literature was the understanding that cultural ES are not uniformly perceived by all people, but rather, the perceived benefits vary with changing circumstances, cultural and social shifts, policy regimes, population groups, and other social characteristics (Spangenberg et al. 2014). Accordingly, researchers understood that the focus on socio-cultural meaning of ES demanded the research community to define the cultural ES through the lens of the beneficiaries themselves (Jax 2010, Menzel and Teng 2010, Chan et al. 2012, Spangenberg et al. 2014).

How the social sciences have been and could be further integrated into ecosystem service assessment

The science of ES assessment is young (approximately 10 years old), and assessment of cultural ES even younger, but social science-based assessment can draw lessons from a broad range of disciplines, including sociology, anthropology, environmental psychology, environmental history, and landscape architecture. Researchers in these fields have been investigating humanenvironment interactions long before the development and proliferation of the ES conceptual framework, and continue to do so today outside the ES framework (Milcu et al. 2013, Russell et al. 2013, Singh et al. 2013). These disciplines are equipped with the methodological tools and theoretical foundations to assess the nature of human-environment interactions and the role of cultural ES.

Recent social research on ES has produced two central contributions to the field: (1) theoretical work suggesting conceptual and structural changes in the ES framework that would better assess ES (particularly cultural ES) from multiple perspectives (e.g., Chan et al. 2012, Luck et al. 2012, Raymond et al. 2013), and (2) research applying social science methodologies toward defining what ES are important to stakeholders and how that knowledge has been, or might be, integrated into the policymaking process (e.g., Gee and Burkhard 2010, Martín-López et al. 2014, Spangenberg et al. 2014). In contrast to quantitative ecological or economic values, social value of cultural ES is generally inferred from qualitative research that focuses on the interactions between human society and the natural environment or from quantitative survey data.

A first step in identifying ES is by querying the recipients of those services and developing a synthesis of expert and local knowledge (Maynard et al. 2010, Raymond et al. 2010). Expert knowledge relies on those with the scientific wherewithal to be able to identify the myriad ways human well-being is dependent on ecosystem processes. Local knowledge complements this knowledge with the identification of what about ecosystems is perceived to matter most to people. Local knowledge is the information source for assessing cultural services in the broad sense, and for understanding socio-cultural meaning of cultural ES to specific individuals and groups in particular.

Methodologies drawn from various social sciences and humanities have been applied to ES assessment, including public opinion surveys (Gee and Burkhard 2010, Sodhi et al. 2010, Martín-López et al. 2014), in-depth interviews (Sagie et al. 2013, Spangenberg et al. 2014), group deliberation (Palacios-Agundez et al. 2014), participatory GIS mapping (Brown et al. 2011, Fagerholm et al. 2012), or some combination of these (Cowling et al. 2008, Maynard et al. 2010, Raymond et al. 2013). Some of these methods were designed to measure perceptions regarding ES in various landscapes, and others were designed to complete broader ES assessments complementing expert knowledge.

In summary, two of the major goals and contributions of social science-based assessments in general have been (1) to provide a mechanism(s) for nonmonetary valuation of ES, and (2) to highlight the diverse ways that humans attribute benefits from ecosystems within a broader understanding of complex socialecological systems.

\section{Environmental "tastes" and the development of a framework for social valuation of cultural ecosystem services}

We integrate social theory and social research methods into ES assessment in order to propose a novel way to assess how individuals perceive and use their local ecosystem. We measure individual perceptions of environmental characteristics as a proxy for ES in order to define distinct environmental "tastes." These tastes represent general dispositions, preferences, or orientations regarding cultural aspects of the environment. In the next step, and in order to introduce the broader potential relevancy of measuring ES as environmental tastes, we use these environmental tastes to explain environmental behaviors (e.g., engagement in outdoor activities and resource conservation efforts) and opinions (e.g., perceived economic dependence from the environment and opinions regarding environmentally focused development issues). Thus, we are able to articulate the link between cultural ES measured as particular sets of environmental tastes that are seen as inclinations or dispositions toward the environment, and an array of environmental practices and opinions.

Our contribution is twofold. First, we identify specific sociocultural dimensions of attachment to the environment or socio- 
cultural meaning of ES, which we term environmental tastes, and show how they have different consequences for environmental behavior and opinion. Second, and on a more general level, we reveal how applying social science-based research to the study of ES assessment can guide us toward a more integrated and complex understanding of human-environment relations. Thus, we provide information for the identification, characterization, and valuation of cultural ES and possible building blocks for future social assessments of ES.

To develop a new formulation for valuation of cultural ES, we draw from three bodies of sociological knowledge: environmental sociology, environmental psychology, and sociology of consumption. As noted, environmental tastes represent dispositions or inclinations that capture the cultural aspect of ES and the interactions between people and place. For example, landscape research in the social sciences focuses on the way individuals use, perceive, transform, debate, and define the landscape, and as a site where memories and identifications are formed (Tengberg et al. 2012). The environment does not only bear physical aspects such as landforms or land surface, but also psychological, historical, and social connotations. In that sense, the environment is the result of interactions between humans and nature, and we aim to capture this interaction through measuring environmental tastes. We hypothesize that if environmental tastes indeed capture a significant aspect of the human-nature interaction, this construct would be significantly associated with how individuals think about the environment and how they act upon it.

To develop the measure of environmental tastes, we turn to the sociology of consumption literature and build on Bourdieu's (1984) theory of taste and its application within environmental research (Bourdieu and Wacquant 1992, Horton 2003). Bourdieu defined tastes as acquired dispositions that individuals use to evaluate and differentiate things in the social world. In the context of environmental research, these tastes reflect dispositions toward such things as nature, sustainability, preservation, landscape, and daily consumption practices, and form a set of dispositions that generate perceptions and practices (Crossley 2003, HaluzaDeLay 2008, Sela-Sheffy 2011). These practices, or in our terms, environmental behaviors, are embedded in individuals' lifestyles and are therefore conditioned by particular social contexts. For example, Carfagna et al. (2014) report a class of ethical consumers characterized by a high cultural capital who exhibit an eco-habitus that encourages environmental awareness and sustainability principles.

To test whether our proposed measure of cultural ES has any consequences, we draw from sociological and psychological literature on pro-environmental behavior, which focus on both socio-demographic variables and social-psychological constructs as correlates of behavior (Dietz et al. 1998). A number of studies showed consistent effects of education and age on environmental attitudes and behaviors (Jones and Dunlap 1992) but overall weak explanatory power attributed to socio-demographics (Diamantopoulos et al. 2003). Socio-psychological factors associated with environmental behavior, such as values and beliefs, have been more successful than socio-demographic dimensions in predicting pro-environmental behaviors (Boldero 1995, Guagnano et al. 1995, de Groot and Steg 2008). These works are based on the premise that individuals' behavior toward the environment should have something to do with what they feel and think with respect to the environment and with respect to environmental action. For example, the value-belief-norm theory (Stern 2000) has shown how environmental behaviors stem from the acceptance of particular personal values and from beliefs that things important to those values are under threat. Following this literature, we propose that environmental tastes would matter for various environmental opinions and activities, and we explore several different measures of such opinions and activities to make our illustration more rigorous. These include two measures of environmental behavior (outdoor activities and private sphere behavior), opinion on perceived economic derived from the ecosystem, opinion on development issues, and environmental concern.

We ask two research questions. First, we ask whether there are distinct dimensions of environmental tastes that represent affinities for specific characteristics of the environment. We maintain that these taste clusters, if they exist, can be theorized as representations of the cultural benefits people derive from ecosystems. Second, we ask whether these dimensions provide potential explanatory power regarding types of environmental behaviors and opinions. In other words, we ask whether environmental tastes, interpreted as measures of cultural ES, have real consequences for environmental behaviors and opinions. Further, we explore the relative contribution of environmental tastes and demographic variables to explaining differences in behaviors and opinions. ${ }^{[1]}$

\section{METHODS}

\section{Research site}

Our research area is the southern Arava Valley in Israel (Fig. 1). The Arava Valley is a hyperarid desert with an annual average rainfall of less than $30 \mathrm{~mm}$. The valley is bounded by the Negev Mountains to the west, the Dead Sea to the north, the Gulf of Aqaba/Eilat to the south, and the Jordanian Araba Valley to the east. Our research focused on communities in the Hevel Eilot Regional Council that were located on the valley floor in the southern half of the valley, which included six kibbutzim ${ }^{[2]}$ and one exurban community. We also included the southern coastal city of Eilat. The Arava Valley research site has proven particularly relevant for studying human-environment interactions, as its population has been shown to be particularly aware of its unique geographical, climatological, and ecological setting (Sagie et al. 2013, Orenstein and Groner 2014).

The population of the Israeli southern Arava Valley (Eilot Regional Council) in 2008 was 3000, and the population of Eilat was 47,300 (Central Bureau of Statistics of Israel 2010) ${ }^{[3]}$ Both Eilat and the Eilot Regional Council are in the middle range of Israel's socioeconomic rankings (with a ranking of 5 on a scale of 1 to 10) (Central Bureau of Statistics of Israel 2010). Economic income in Hevel Eilot is based primarily on agriculture, services, tourism, and light industry. In Eilat, income is through tourism, trade, real estate and other businesses. 
Fig. 1. Map of research site.

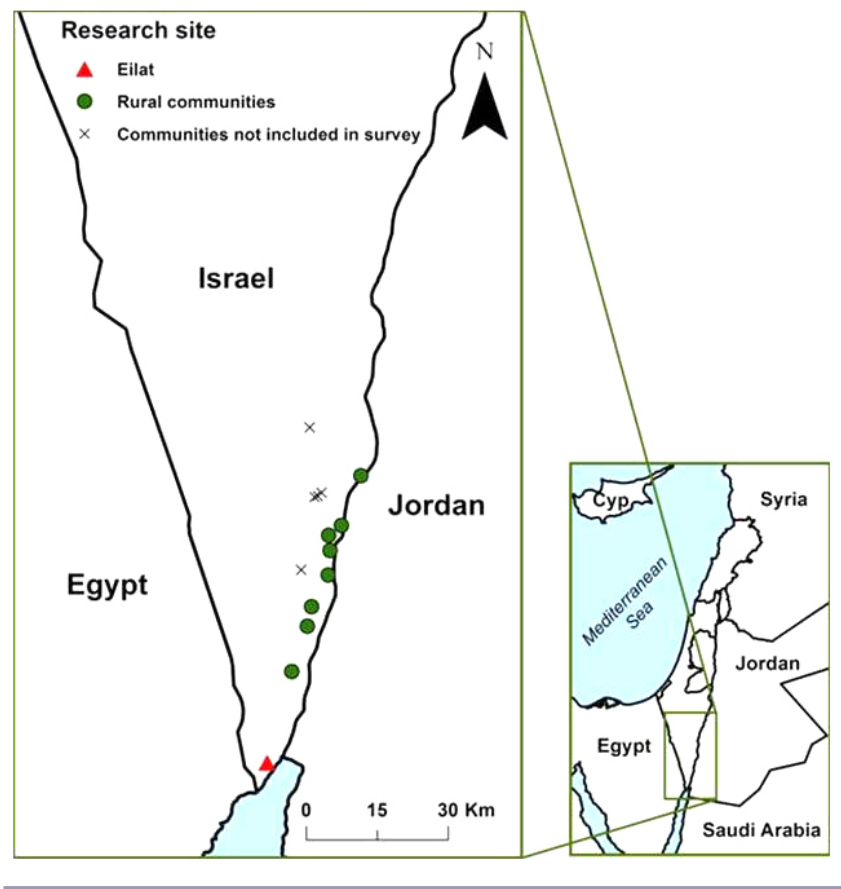

\section{Survey}

We distributed questionnaires in Israel's southern Arava Desert, including in seven rural communities and the coastal city of Eilat. The method of survey distribution varied in each community according to local constraints and concerns. In each rural community, the research team made contact with a local resident and/or with the administrators of the community to inquire about the best way to distribute questionnaires in that community. In some sites, questionnaires were distributed door-to-door, and completed surveys were collected several hours later. In others, questionnaires were distributed outside the communal dining hall during meal times, where they were filled in and returned. In Eilat, researchers chose a diversity of public areas, including outdoor and indoor shopping malls, restaurants, a university campus, a retirement home, and tourist sites to distribute and collect questionnaires. We received 257 completed surveys, of which 78 were from the city of Eilat and 179 were from the rural communities of the southern Arava. We purposely over-sampled the rural communities because each has its own unique character (thus we sampled in each one and did not treat them as a single unit) and because they have small populations and we desired to reduce variance in our samples.

The design of the questionnaires was crafted to reveal whether local residents were aware of the services they receive from their ecosystem. Prior to designing the survey, we conducted a series of interviews with 10 community leaders (including political and business leaders, educators, activists, and scientists) to obtain information regarding relevant environmental issues, perceptions, and economic activities in the region. The results from these interviews and others are reported in Sagie et al. (2013). We learned from these interviews that the term "ecosystem services" was neither recognized nor intuitively understood by most respondents (a result also noted by the authors of UK-NEA [2011]). Thus, in the questionnaire, we did not use the term ecosystem services explicitly, but rather crafted questions whose answers could provide proxy measures for awareness regarding ecosystem services. As such, batteries of questions dealt with respondents' appreciation of various ecological and geological characteristics of their local environment (cultural ES), their recreational activities in their environment (cultural ES), and their perceived economic dependence on these characteristics (provisioning, cultural, or regulating ES). To measure behaviors and opinions, we used sets of questions that frequently feature in research on these issues (e.g., Guagnano et al. 1995, Stern 2000, de Groot and Steg 2008).

\section{Variables}

\section{Environmental characteristics}

We used a series of questions about environmental characteristics that serve as proxy measures for cultural ES. These questions assist in determining which physical and biological components of the ecosystem are valued by respondents. Such characteristics, when highly valued by the respondent and directly linked to biodiversity or geodiversity, are considered to be cultural ES (UKNEA 2011). Respondents were asked to rank a list of environmental characteristics of their environment with regard to how much they appreciate them on a scale from 1 (strongly dislike) to 5 (strongly like). The characteristics included heat, aridity, openness, brightness/glare, sand dunes, quiet, dust/sand storms, mountains, landscape, animals, insects, shrubs, acacia trees, corals, and distance (from the rest of the country). We interpret such characteristics as indicating certain inclinations or dispositions that pertain to aesthetic, spiritual, emotional, climatic, landscape, and other qualities, considered together as "environmental tastes," as elaborated in the Results section.

\section{Environmental behaviors}

To measure behaviors, we used a set of questions on frequency of engagement in outdoor recreational activities, which indicate a form of human interaction with the ecosystem (Paracchini et al. 2014), and a set of questions on private sphere environmental behavior. To measure outdoor activities, respondents were asked to indicate the frequency of engaging in a list of activities, ranging from 1 (never) to 5 (almost every day). The activities included walking outside, walking outside in agricultural areas, hiking in the desert/mountains, riding bikes in the desert/mountains, riding on animals (horse/camel), driving motorcycles or off-road vehicles in the desert/mountains, swimming in the Gulf of Eilat, birding, snorkeling/scuba diving in the Gulf of Eilat, camping in the desert/mountains, spending time relaxing/building bonfires in the desert/mountains, and collecting animals/plants/minerals from their surroundings. These questions are another indicator of cultural ES, specifically when the outdoor activity is focused on biological or geological components of the landscape. To measure private sphere environmental behavior, we asked respondents to rank how often they engage in particular environmental behaviors, including turning off appliances and lights when not in use, recycling, walking, or riding a bike in lieu of using a motor vehicle (for environmental reasons), saving water, using energy-efficient light bulbs, and re-using bags or using cloth bags for shopping. Ranking was from 1 (never) to 4 (always). 
Opinions: perceived economic dependence

We used a set of questions on perceived economic dependence from the environment as an indicator of provisioning, regulating, and/or supporting services. Respondents were asked to indicate the extent to which a list of natural resources provides economic benefits to them or their communities on a scale from 1 (never) to 4 (my economic well-being is dependent on this resource). The list of resources included water, soil, sun/heat, insects, birds, corals, animals (other than those previously mentioned), minerals (e.g., sand, copper), aridity, and open land. ${ }^{[4]}$ These questions provide insight into whether the respondent perceives an economic reliance on ecosystem services, regardless of whether or not it is true in economic terms. Through these questions, we generated an indicator of how aware respondents were regarding their dependence on ecosystems and the services they provide. Treating this question as a perception of their economic dependence, we expected a high degree of awareness within the study population due to the importance of agriculture and tourism to the local economy.

Opinions: development issues

As an additional measure of opinions, we queried respondents about general environmental issues and specific, local, development issues. Respondents were asked to indicate the extent to which they agreed or disagreed with a series of statements regarding local and regional development issues, on a scale from 1 (strongly disagree with the statement) to 5 (strongly agree with the statement). We chose topics based on our a priori knowledge of local and regional issues, supplemented with issues that were raised in the semistructured interviews conducted prior to writing the questionnaire.

\section{Opinions: environmental concern}

We asked respondents about their level of concern regarding regional and global environmental issues. They were asked to rank their level of "worry" regarding a series of local to global-scale environmental challenges, including climate change, water quality and quantity, river pollution, toxic waste storage and disposal, species conservation, open space conservation, public access to beaches, and local level of recycling. Respondents ranked their opinions from 1 (not worried at all) to 5 (very worried).

\section{Socioeconomic and demographic characteristics}

This section in the questionnaire included questions about gender (male, female), place of residence (see details in Table 6), age, household status (single, married, cohabiting), number of children, years lived in the region, and level of formal education (elementary school, high school, undergraduate degree, graduate degree and higher).

\section{RESULTS}

\section{Descriptive statistics}

\section{Environmental tastes}

Mean values for preference for each environmental characteristic are shown in Fig. 2. They reflect a general affinity with most of the environmental characteristics of the region. Respondents had, on average, a positive opinion regarding 11 of 15 environmental characteristics, and a negative opinion of only two of them (insects and dust/sand storms). Landscape, mountains, quiet, and open space were consistently chosen as the most appreciated characteristics of the environment. We conducted a factor analysis for opinions regarding environmental characteristics to extract environmental tastes, which we consider to indicate perceptions regarding cultural ES.

Behavior: level of engagement in outdoor recreational activities Engagement in outdoor activities is considered a measure of cultural ES (Paracchini et al. 2014). Table 1 displays the distribution of frequency of engagement in these activities. Walking was by far the most prevalent outdoor activity from among the choices offered, with $87 \%$ of the respondents reporting that they walk at least once or twice a month (34\% reporting that they walk almost every day). At the opposite end of the spectrum, most respondents reported that they never bike (53\%), go animal riding $(77 \%)$, use off-road vehicles $(70 \%)$, go snorkeling $(33 \%)$, go birding $(62 \%)$, or go collecting $(67 \%)$.

Fig. 2. Mean values of preferences in descending order.

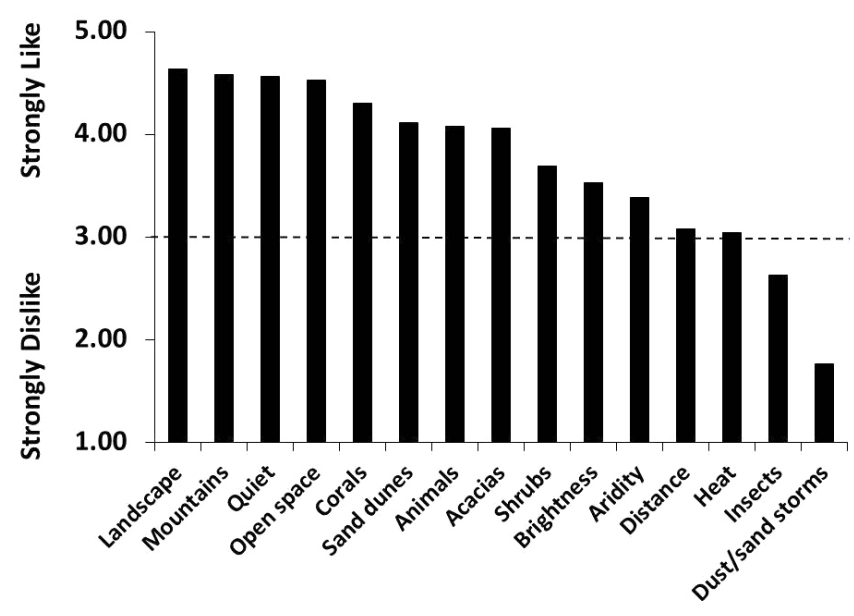

Table 1. Frequency of engagement in outdoor activities.

\begin{tabular}{|c|c|c|c|c|c|}
\hline \multirow[t]{2}{*}{ Activity } & \multicolumn{5}{|c|}{ Frequency of activity ( $\%$ of valid responses) } \\
\hline & Never & $\begin{array}{c}\text { Once or } \\
\text { twice a } \\
\text { year }\end{array}$ & $\begin{array}{l}\text { Once } \\
\text { or } \\
\text { twice a } \\
\text { month }\end{array}$ & $\begin{array}{c}\text { Once } \\
\text { or } \\
\text { twice a } \\
\text { week }\end{array}$ & $\begin{array}{c}\text { Almost every } \\
\text { day }\end{array}$ \\
\hline Walking & 4 & 9 & 22 & 31 & 34 \\
\hline $\begin{array}{l}\text { Walking in } \\
\text { agricultural } \\
\text { areas }\end{array}$ & 19 & 24 & 28 & 15 & 15 \\
\hline Hiking & 11 & 32 & 40 & 14 & 4 \\
\hline Biking & 53 & 24 & 13 & 7 & 4 \\
\hline Animal riding & 77 & 15 & 4 & 3 & 1 \\
\hline $\begin{array}{l}\text { Off-road } \\
\text { vehicles }\end{array}$ & 70 & 16 & 11 & 2 & 2 \\
\hline Swimming (gulf) & 19 & 35 & 29 & 13 & 3 \\
\hline Snorkling/scuba & 33 & 31 & 24 & 9 & 2 \\
\hline Birding & 62 & 24 & 10 & 2 & 2 \\
\hline Camping & 36 & 46 & 15 & 2 & 1 \\
\hline Campfires & 25 & 51 & 19 & 4 & 1 \\
\hline Collecting & 67 & 20 & 8 & 2 & 3 \\
\hline
\end{tabular}


Behavior: private sphere environmental behavior

Table 2 shows that respondents reported a high frequency of activity in all of the categories of private sphere environmental behavior, with the exception of walking/bike riding in lieu of using motor vehicles. Not including this question, more than $80 \%$ of the respondents reported that they sometimes or always engage in environmental behaviors in every category. We note an important caveat regarding the question of walking/bike riding: because they work in close proximity to their homes, most of the residents of the rural sector included in the survey used walking $(37 \%)$ or bike riding $(21 \%)$ as their primary means to commute to work (Central Bureau of Statistics of Israel 2010). So, although numbers of reported walkers/riders were low, they may be low due to the question's stipulation "for environmental reasons." According to the 2008 census, $16 \%$ of residents in the city of Eilat also use walking or bike riding as their means of commuting to work.

Table 2. Private sphere environmental behaviors.

\begin{tabular}{lcccc}
\hline \hline Behavior & \multicolumn{3}{c}{ Frequency of activity (\% of valid responses) } \\
\cline { 2 - 5 } & Never & $\begin{array}{c}\text { Once in a } \\
\text { while }\end{array}$ & Sometimes & Always \\
\hline $\begin{array}{l}\text { Turn off } \\
\text { appliances and }\end{array}$ & 2 & 2 & 28 & 68 \\
$\begin{array}{l}\text { lights when not in } \\
\text { use }\end{array}$ & & & & \\
$\begin{array}{l}\text { Recycle paper/ } \\
\text { cans/bottles }\end{array}$ & 4 & 8 & 33 & 56 \\
$\begin{array}{l}\text { Walk or ride bike } \\
\text { instead of drive } \\
\text { for environmental } \\
\text { reasons }\end{array}$ & 30 & 22 & 28 & 20 \\
$\begin{array}{l}\text { Save water (e.g., } \\
\text { take short } \\
\text { showers, turn off } \\
\text { water when }\end{array}$ & 6 & 10 & 43 & 42 \\
washing dishes) & & & & \\
$\begin{array}{l}\text { Use energy } \\
\text { efficient light } \\
\text { bulbs }\end{array}$ & 8 & 6 & 30 & 56 \\
$\begin{array}{l}\text { Re-use bags or use } \\
\text { cloth bags when } \\
\text { shopping }\end{array}$ & 9 & 7 & 32 & 52 \\
\hline
\end{tabular}

Opinion: perceived level of economic dependency received from environmental resources

Table 3 displays the distribution of the perceived level of economic dependency on natural resources/environmental characteristics questions. Two clear trends emerge. On the one hand, a large number of respondents noted total economic dependency on water, soil/land, and sun/heat. On the other, for every other resource or environmental characteristic, including insects, birds, other animals, minerals, aridity, and open space, the highest proportion of respondents noted that they are not at all dependent on them. What is also notable about this latter group of resources/ environmental characteristics is that between one-fifth and onequarter of the respondents did not know if their economic wellbeing depends on the resources or not.
Opinion: opinions regarding development issues of contemporary concern in the Arava Valley

The list of issues is presented in Table 4, along with results. We offer several preliminary observations regarding the results to these opinion questions, which are analyzed further in this section and in the Discussion. First, the overall tendencies of the respondents were toward environmental protection, with high percentages of respondents strongly agreeing with general statements regarding the importance of protecting habitats and biodiversity. Further, respondents largely rejected the statement that suggested that economic development should take place at the expense of environmental protection. Accordingly, respondents expressed support for balancing economic and environmental needs and reflected a belief that these can occur together. On specific development issues, opinion was most divided with regard to the construction of a new international airport, with one-fifth expressing strong opposition and one-fifth expressing strong support. Half the sample supported the statement that there were not enough people living in the Arava, and half supported the statement that tourism infrastructure development is important. Expanding agricultural activity could have been considered a controversial issue due to its demands on water and open space resources, on the one hand, and due to its significant contribution to the local economy, on the other, but most of the respondents either supported or strongly supported $(44 \%)$ or were indifferent $(30 \%)$ about expanding date orchards.

Table 3. Perceived dependency on natural resources and environmental characteristics.

\begin{tabular}{lccccc}
\hline \hline $\begin{array}{l}\text { Resource/ } \\
\text { Characteristic }\end{array}$ & \multicolumn{5}{c}{ Level of economic dependency (\% of valid } \\
& $\begin{array}{c}\text { Not at } \\
\text { all }\end{array}$ & A little & A lot & $\begin{array}{c}\text { Totally } \\
\text { dependent }\end{array}$ & Don't know \\
\cline { 2 - 6 } & 18 & 7 & 14 & 49 & 9 \\
\hline Water & 20 & 11 & 15 & 43 & 9 \\
Soil/land & 20 & 11 & 21 & 40 & 8 \\
Sun/heat & 56 & 14 & 4 & 3 & 22 \\
Insects & 48 & 18 & 9 & 4 & 20 \\
Birds & 45 & 16 & 8 & 9 & 22 \\
Animals (other) & 48 & 17 & 12 & 2 & 21 \\
Minerals & 40 & 16 & 13 & 8 & 22 \\
Aridity & 32 & 10 & 22 & 11 & 25 \\
Open space & \multicolumn{5}{c}{}
\end{tabular}

Opinion: level of concern regarding regional and global environmental issues

Table 5 shows results for questions that queried levels of concern regarding environmental issues. Overall, there was a high level of concern for environmental challenges across all categories. Toxic waste treatment, river pollution, and water quality and quantity ranked highest, while the level of recycling in their region and climate change ranked lowest from among the choices.

\section{Socioeconomic and demographic characteristics}

Descriptive statistics of these variables are presented in Table 6. The age distribution of our sample was fairly even across age categories, with a slight bias toward middle and older age categories (30-69 years) as compared to the actual population (Central Bureau of Statistics of Israel 2010). Men were slightly over sampled ( $58 \%$ of the total sample). Household status (single, 
Table 4. Opinions regarding selected issues pertaining to regional development, environmental protection, or use/importance of environment.

\begin{tabular}{|c|c|c|c|c|c|c|}
\hline \multirow[t]{2}{*}{ Statement } & \multicolumn{6}{|c|}{ Level of agreement ( $\%$ of valid responses) } \\
\hline & $\begin{array}{l}\text { Strongly } \\
\text { disagree }\end{array}$ & $\begin{array}{c}\text { Somewhat } \\
\text { disagree }\end{array}$ & Neutral & Somewhat agree & Strongly agree & Don’t know \\
\hline $\begin{array}{l}\text { There are not enough people living in the } \\
\text { southern Arava/Eilat }\end{array}$ & 9 & 19 & 20 & 30 & 20 & 2 \\
\hline $\begin{array}{l}\text { Most tourists come to the region because of } \\
\text { the natural environment (geology, ecology, } \\
\text { aesthetics) }\end{array}$ & 5 & 24 & 13 & 29 & 23 & 6 \\
\hline $\begin{array}{l}\text { The economic benefits of building a hotel in } \\
\text { Emek Sasgon (Timna) outweigh the } \\
\text { environmental costs }\end{array}$ & 34 & 19 & 16 & 9 & 11 & 11 \\
\hline $\begin{array}{l}\text { It is important to construct an international } \\
\text { airport in the Arava (in Israel) }\end{array}$ & 21 & 18 & 15 & 20 & 22 & 2 \\
\hline $\begin{array}{l}\text { "Environmentalists" are too extreme in their } \\
\text { desire to prevent development in the Arava }\end{array}$ & 15 & 19 & 30 & 20 & 13 & 4 \\
\hline $\begin{array}{l}\text { Date farming should be expanded in the } \\
\text { southern Arava }\end{array}$ & 3 & 12 & 30 & 23 & 21 & 11 \\
\hline I am very environmental in my behaviors & 1 & 8 & 33 & 37 & 20 & 2 \\
\hline $\begin{array}{l}\text { My community is very environmental in its } \\
\text { behaviors }\end{array}$ & 4 & 18 & 29 & 32 & 12 & 4 \\
\hline $\begin{array}{l}\text { Economic development should always take } \\
\text { precedent over environmental protection }\end{array}$ & 24 & 44 & 17 & 7 & 6 & 2 \\
\hline $\begin{array}{l}\text { Economic development and environmental } \\
\text { protection can occur together }\end{array}$ & 1 & 8 & 8 & 47 & 35 & 2 \\
\hline $\begin{array}{l}\text { Developing tourism infrastructure in the } \\
\text { Arava is important for the future of the } \\
\text { region }\end{array}$ & 2 & 5 & 9 & 44 & 39 & 1 \\
\hline $\begin{array}{l}\text { My economic well-being depends on a } \\
\text { clean, healthy environment }\end{array}$ & 2 & 9 & 20 & 34 & 33 & 2 \\
\hline $\begin{array}{l}\text { It is important to protect Arava sand dunes } \\
\text { from development }\end{array}$ & 1 & 6 & 14 & 31 & 46 & 3 \\
\hline $\begin{array}{l}\text { It is important to protect biodiversity in the } \\
\text { southern Arava and the Gulf of Eilat, even } \\
\text { if it means foregoing economic } \\
\text { opportunities }\end{array}$ & 0 & 6 & 19 & 32 & 39 & 4 \\
\hline I enjoy spending time in nature & 2 & 2 & 8 & 37 & 50 & 0 \\
\hline
\end{tabular}

Table 5. Degree of concern regarding selected local to global scale environmental challenges.

\begin{tabular}{lccccc}
\hline \hline & \multicolumn{5}{c}{ Degree of concern (\% of valid responses) } \\
\cline { 2 - 6 } & $\begin{array}{c}\text { Not at } \\
\text { all } \\
\text { worried }\end{array}$ & $\begin{array}{c}\text { Not } \\
\text { very } \\
\text { worried }\end{array}$ & Neutral & $\begin{array}{c}\text { Some- } \\
\text { what } \\
\text { worried }\end{array}$ & $\begin{array}{c}\text { Very } \\
\text { worried }\end{array}$ \\
\hline Toxic waste storage and & 1 & 4 & 5 & 26 & 64 \\
disposal & 2 & 5 & 6 & 26 & 61 \\
Water quality/quantity & 2 & 3 & 7 & 30 & 58 \\
River pollution & 1 & 6 & 11 & 27 & 56 \\
Public beach access & 1 & 3 & 13 & 34 & 49 \\
Species conservation & 2 & 3 & 11 & 36 & 48 \\
Open space & & & & & \\
conservation & 4 & 6 & 9 & 40 & 41 \\
Climate change & 3 & 8 & 15 & 39 & 36 \\
Local recycling rates & & & & & \\
\hline
\end{tabular}

married, cohabitating) accurately reflected the actual population distribution. The formal educational achievement of our sample, and fertility (number of children per mother) were also similar to those of the general population, with a slight bias in the sample toward higher educational attainment.

\section{Analytic approach}

The analysis was carried out in three stages. First, we conducted a factor analysis for opinions regarding "environmental characteristics" to extract environmental tastes, which we consider to indicate perspectives regarding cultural ES. Second, we had to decide whether to treat the measures of behaviors and opinions as separate indicators, as indices, or as weighted indices (factors). We factor analyzed all the relevant batteries to explore whether they had an underlying structure and decided to treat them as follows:

1. We used factor analysis for the battery of questions on engagement in "outdoor activities" and the battery of perceived "economic dependency on environmental resources," which revealed theoretically coherent and empirically separate dimensions. 
Table 6. Demographic characteristics of survey sample.

\begin{tabular}{|c|c|c|c|c|c|c|c|c|c|c|}
\hline \multicolumn{11}{|c|}{ Demographics of sample } \\
\hline $\begin{array}{l}\text { Gender } \\
(\%)\end{array}$ & $\begin{array}{l}\text { Female } \\
42 \%\end{array}$ & $\begin{array}{l}\text { Male } \\
58 \%\end{array}$ & & & & & & & & \\
\hline $\begin{array}{l}\text { Age } \\
(\%)\end{array}$ & $\begin{array}{c}15-19 \\
3 \%\end{array}$ & $\begin{array}{c}20-29 \\
21 \%\end{array}$ & $\begin{array}{c}30-39 \\
22 \%\end{array}$ & $\begin{array}{c}40-49 \\
25 \%\end{array}$ & $\begin{array}{c}50-59 \\
18 \%\end{array}$ & $\begin{array}{c}60-69 \\
9 \%\end{array}$ & $\begin{array}{l}70+ \\
2 \%\end{array}$ & & & \\
\hline $\begin{array}{l}\text { Place of residence } \\
(N)\end{array}$ & $\begin{array}{c}\text { Eilat } \\
78\end{array}$ & $\begin{array}{c}\text { Beer Ora } \\
3\end{array}$ & $\begin{array}{c}\text { Eliphaz } \\
13\end{array}$ & $\begin{array}{l}\text { Samar } \\
28\end{array}$ & $\begin{array}{c}\text { Yotvata } \\
35\end{array}$ & $\begin{array}{l}\text { Grofit } \\
25\end{array}$ & $\begin{array}{c}\text { Ketura } \\
33\end{array}$ & $\begin{array}{c}\text { Lotan } \\
24\end{array}$ & $\begin{array}{c}\text { Yahel } \\
14\end{array}$ & $\begin{array}{c}\text { Other } \\
2\end{array}$ \\
\hline $\begin{array}{l}\text { Household status } \\
(\%)\end{array}$ & $\begin{array}{l}\text { Single } \\
44 \%\end{array}$ & $\begin{array}{c}\text { Married } \\
49 \%\end{array}$ & \multicolumn{2}{|c|}{$\begin{array}{c}\text { Cohabitating } \\
7 \%\end{array}$} & & & & & & \\
\hline $\begin{array}{l}\text { Number of children } \\
(\%)\end{array}$ & $\begin{array}{l}\text { None } \\
32 \%\end{array}$ & $\begin{array}{c}1-2 \\
48 \%\end{array}$ & $\begin{array}{c}3-5 \\
18 \%\end{array}$ & \multicolumn{2}{|c|}{$\begin{array}{l}6 \text { or more } \\
2 \%\end{array}$} & & & & & \\
\hline $\begin{array}{l}\text { Years lived in region } \\
(\%)\end{array}$ & $\begin{array}{c}0-5 \\
28 \%\end{array}$ & $\begin{array}{l}6-10 \\
12 \%\end{array}$ & $\begin{array}{c}11-20 \\
19 \%\end{array}$ & $\begin{array}{c}21-30 \\
24 \%\end{array}$ & $\begin{array}{l}30+ \\
17 \%\end{array}$ & & & & & \\
\hline $\begin{array}{l}\text { Formal education } \\
(\%)\end{array}$ & \multicolumn{2}{|c|}{$\begin{array}{c}\text { Elementary } \\
0 \%\end{array}$} & \multicolumn{2}{|c|}{$\begin{array}{l}\text { High school } \\
51 \%\end{array}$} & \multicolumn{3}{|c|}{$\begin{array}{l}\text { Undergraduate degree } \\
32 \%\end{array}$} & \multicolumn{3}{|c|}{$\begin{array}{l}\text { Graduate degree and higher } \\
17 \%\end{array}$} \\
\hline
\end{tabular}

2. We treated the questions regarding "level of concern" and the questions on "private sphere environmental behavior" as summed scales because both of them produced only one dimension in factor analysis and in a reliability test. We used Cronbach's alpha as a measure of internal consistency between items forming a single scale. The items forming the private sphere behavior scaled at 0.703 , and the items forming level of concern scaled at 0.869 .

3. The items measuring opinions regarding development issues pertained to several very different issues. These items did not form a scale, nor did we expect them to represent distinct underlying dimensions; therefore, we treated them as separate questions.

Finally, we conducted multivariate analyses to estimate the effect of environmental tastes (opinions regarding environmental characteristics) and socio-demographic variables (gender, residential tenure, marital status, education, urban/rural residency, age, number of children) on measures of behavior (engagement in outdoor activities, private sphere environmental behavior) and measures of opinion (perceived economic dependency, level of concern, development attitudes).

\section{Factor analysis}

We applied factor analysis on the battery of questions measuring level of appreciation of "environmental characteristics," in order to identify clusters of environmental tastes. Factor analysis is a method of data reduction, which seeks underlying latent variables that are reflected in the observed variables. For all analyses, we applied principal component factor analysis with varimax rotation. Rotated factor loadings on the three factors that emerged are shown in Table 7.

Each factor clustered a group of related variables that revealed particular affinities, or "tastes," for particular components of the desert environment. The first dimension, which we termed
Table 7. Rotated factor loadings for environmental tastes.

\begin{tabular}{lccc}
\hline \hline & Landscape & Biota & Desert \\
\hline Open space & .714 & .187 & .130 \\
Mountains & .709 & .276 & .194 \\
Landscape & .640 & .154 & .253 \\
Corals & .631 & .185 & -.042 \\
Quiet & .616 & .120 & -.025 \\
Sand dunes & .569 & .438 & .121 \\
Brightness & .474 & -.068 & .472 \\
Shrubs & .293 & .786 & -.018 \\
Insects & .088 & .739 & .172 \\
Animals & .250 & .728 & .079 \\
Acacias & .495 & .642 & .076 \\
Aridity & -.034 & .242 & .713 \\
Heat & .281 & -.290 & .671 \\
Dusts/sand storms & .037 & .326 & .606 \\
Cumulative \% of & 34.9 & 46.2 & 55.1 \\
variance explained & & & \\
\hline
\end{tabular}

"landscape," included characteristics associated with the visual and sensory landscape, including sand dunes, corals, quiet, landscapes, open space, and brightness. The next dimension, which we labeled "biota," included all of the living elements of the environment, including shrubs, insects, wild animals, and acacias. Corals were not included in the "biota" taste dimension, and we speculate that many individuals may relate to corals as characteristics of the view, and not as living creatures. The third dimension, which we termed "desert," featured those climatic characteristics that define the extreme environment-heat, aridity, dust, and brightness. Notably, each of these components was ranked with the lowest degree of preference, on average (Fig. 2).

The factor analysis for the battery of questions that queried frequency of engagement in various outdoor activities yielded 
two dimensions of activity (Table 8). The first concentrated all the activities associated with greater speed or action (off-road vehicles, swimming in the gulf, riding, biking) in addition to camping and campfires. The second dimension concentrated all of the slower activities (walking, collecting, birding, hiking). We note that these two dimensions could be compared by the pace and concentration at which a person observes the landscape and its biological components. Therefore, we labeled these dimensions "active" and "pensive," accordingly.

Table 8. Rotated factor loadings for outdoor activities.

\begin{tabular}{lcc}
\hline \hline & Active & Pensive \\
\hline Campfires & .802 & .087 \\
Camping & .778 & .050 \\
Off-road vehicles & .610 & -.111 \\
Swimming in the gulf & .602 & .035 \\
Animal riding & .570 & .156 \\
Biking & .491 & .319 \\
Walking & -.032 & .642 \\
Collecting & -.010 & .633 \\
Birding & .112 & .614 \\
Hiking & .478 & .565 \\
Cumulative \% of variance & 30.63 & 44.48 \\
explained & & \\
\hline
\end{tabular}

For the battery of questions that queried perceived level of economic dependency, factor analysis distinguished between two dimensions, which we termed "physical" and "ecological" (Table 9). The first factor revealed perceived dependency on heat/sun, water, and soil/land. The second factor concentrated biotic components of the landscape, but also open space and minerals. We note that all of the elements in the second factor received low rankings with regard to perceived economic dependence.

Table 9. Rotated factor loadings for perceived economic dependency on selected natural resources or environmental characteristics.

\begin{tabular}{lcc}
\hline \hline & Physical & Ecological \\
\hline Land/soil & .894 & .253 \\
Sun/heat & .877 & .197 \\
Water & .855 & .242 \\
Birds & .220 & .783 \\
Animals (other) & .224 & .751 \\
Minerals & .106 & .732 \\
Open space & .551 & .623 \\
Aridity & .510 & .513 \\
Insects & .384 & .506 \\
Cumulative \% of variance & 53.14 & 65.57 \\
explained & & \\
\hline
\end{tabular}

\section{Multivariate analysis of environmental tastes, behaviors, and opinions}

We tested the relative effect of our environmental taste dimensions (landscape, biota, desert), controlling for the social demographic variables (Table 6), on outdoor activities (active, pensive), private sphere behavior, perceived economic dependency (physical, ecological), and environmental concern. Displayed in Table 10 are the statistically significant standardized effects, which show three main findings. First, very few effects of the sociodemographic variables were statistically significant, indicating that, in general, environmental behaviors and opinions in our sample were not conditioned by characteristics such as gender, age, marital status, etc. Second, five out of the six behaviors and opinions were significantly associated with at least one of the environmental tastes, indicating that this construct played a consistent role in shaping environmental behaviors and opinions. Third, although very few associations were significant, the explained variance in the different models was not negligible in the context of measuring behavior and opinions, ranging from 0.042 to 0.340 . This means that although each model featured only one or two significant associations, these were quite strong.

Looking specifically at the various measures, we see that respondents who appreciate the landscape environmental taste (e. g., mountains, sand dunes) tended to engage in "active" activities (e.g., swimming, animal riding) and to express more concern about the environment; respondents with a taste for the biota (e. g., shrubs, animals) tended to engage in "pensive" activities (e.g., walking, birding); those with a "desert" taste (e.g., aridity, heat) were more likely to report higher economic dependency on "ecological" components of the environment as well as higher scores on the private sphere environmental behavior. There were no consistent effects of the socio-demographic variables on the behavior and opinion measures, and the effects that were significant were in the direction reported in previous research: men are less inclined than women to adopt private sphere proenvironmental behavior; urban dwellers report lower levels of economic dependency on environmental resources than rural residents; and older respondents are less engaged in "active" outdoor activities compared to younger respondents (Orenstein and Groner 2014).

Table 11 displays results of the regression of nine environmental opinion questions that had to do with development issues on environmental tastes and socio-demographic variables. Seven out of nine of the questions had statistically significant associations with the biota taste dimension, suggesting that this dimension is a reflection of stronger environmental opinions. We included the question regarding "not enough population," assuming that more environmental respondents would not support this statement. However, in the Israeli context, and in particular, in the context of the Israeli geographic periphery, support for population growth for socioeconomic reasons tends to overshadow concern for its environmental impact (Orenstein et al. 2011). Somewhat ironically, the statement "I am environmental" was positively associated with the desert and landscape dimensions, which, with one exception, were not positively associated with any other environmental opinion. Of all of the socio-demographic variables, only two-younger and rural-provided explanatory power for the environmental opinion results.

\section{DISCUSSION}

Environmental tastes, ecosystem services, and landscape services In this research, we queried a sample population regarding their perceptions of various features of their natural environment and translated them into socio-cultural meaning they derive from their local ecosystem. We revealed three unique environmental tastes 
Table 10. Standardized coefficients from ordinary least squares regressions of outdoor activity factors, perceived dependency factors, concern, and private sphere behavior on environmental tastes and socio-demographics $*^{*} p<0.05$, ** $p<0.01$; only statistically significant results are reported).

\begin{tabular}{|c|c|c|c|c|c|c|}
\hline & \multicolumn{2}{|c|}{ Outdoor activities } & \multicolumn{2}{|c|}{ Perceived economic dependency } & \multirow[b]{2}{*}{ Environmental concern } & \multirow[b]{2}{*}{$\begin{array}{c}\text { Private sphere } \\
\text { behavior }\end{array}$} \\
\hline & Active & Pensive & Physical & Ecological & & \\
\hline Desert & & & & $0.189 *$ & & $0.163 *$ \\
\hline Biota & & $0.328 * *$ & & & & $0.262 * *$ \\
\hline Landscape & $0.264 * *$ & & & & $0.167^{*}$ & \\
\hline Male & & & & & & $-0.177 * *$ \\
\hline \multicolumn{7}{|l|}{ Tenure } \\
\hline \multicolumn{7}{|l|}{ Married } \\
\hline \multicolumn{7}{|l|}{ Degree } \\
\hline Urban & & & $-0.440 * *$ & $-0.202 *$ & & \\
\hline Age & $-0.422 * *$ & & & & & \\
\hline \multicolumn{7}{|l|}{ Children } \\
\hline Adj. $R^{2}$ & 0.176 & 0.202 & 0.340 & 0.054 & 0.042 & 0.184 \\
\hline$N$ & 210 & 210 & 123 & 123 & 225 & 224 \\
\hline
\end{tabular}

that reflect a split in public preferences for environmental characteristics. "Landscape" is associated with the visual and sensory landscape, "Biota" is associated with living elements of the environment, and "Desert" is associated with the extreme climatic characteristics of the environment.

Defining these tastes in terms of the benefits people receive from ecosystem services presents us with a conundrum that is representative of the larger challenge of defining cultural ES. In the most literal sense, ES are based on a biological dimension of the environment (Reid et al. 2005). In some recent ES research, however, both biotic and abiotic components of the ecosystem are considered to provide services (Gray 2011, UK-NEA 2011, Orenstein and Groner 2014).

Those individuals who express a strong preference for animals and plants clearly place meaning in the biological life, and thus can be said to receive benefits from cultural ES. On the other hand, can those who express a taste for landscape - particularly in this arid landscape characterized by minimal vegetative cover - be said to receive benefits from cultural services? Is this primarily a semantic issue, or is it crucial to delineate a sharp differentiation between ecosystem services, natural resources, and landscape aesthetics? Can we adopt a more pluralistic approach to cultural ecosystem services that looks at the natural environment as a holistic entity comprised of biodiversity, geodiversity, climate, and other characteristics?

We believe that demanding a rigid dichotomy between the biological and other elements of the ecosystem would ultimately diminish the research, management, and pedagogical value of the ES conceptual framework. While scientists and some other stakeholders may trace benefits directly to individual biological components of the ecosystem, other stakeholders express appreciation of the broader landscape. In fact, in four different studies we have conducted in five different regions in three different countries, respondents of surveys consistently gave highest preference ratings to landscape. We thus advocate the pluralistic view that multiple components of the ecosystem, including biological, geological, and climate components, interact and combine to provide diverse forms of culture values for different stakeholders. We adopt the suggestion of Termorshuizen and Opdam (2009), who suggest that all of these elements combine within in the landscape, and thus advocate for the unifying concept of "landscape services," where landscapes include "elements that the locals perceive, valuate, and manage," and whose benefits are not attributed solely to biodiversity (Termorshuizen and Opdam 2009). In short, what stakeholders are valuing may be better described as landscape services rather than cultural ES, and those services include the biophysical environment in its entirety (Brown et al. 2011, Fagerholm et al. 2012).

Environmental tastes: a window into how people use and perceive their environment?

We investigated whether environmental taste dimensions could serve as potential explanatory variables for environmental behaviors and opinions. Our results indicate that environmental tastes indeed have consistent and strong associations with environmental opinions and behaviors. Those individuals who reflect taste for biota engage in activities that are based on biological dimensions of the ecosystem (specifically, birding and collecting), and reflect more pro-environmental behaviors and opinions. Those who reflect a taste for landscape engage in activities that do not necessarily reflect an appreciation of biodiversity but do reflect an affinity for the combined biotic/ abiotic environment (i.e., landscape). While the desert taste also correlates with other variables, there is no clear pattern or obvious explanation for the relationships.

The most interesting phenomenon to surface is the biota environmental taste, which seemingly has wide-ranging impact on subsequent measures of environmental behaviors and opinions. Our data suggest that if a respondent has a taste for biota, they are more inclined to have pro-environmental opinions and behaviors. An affinity for biota is positively associated with "pensive" activities-walking, hiking, collecting, and birding. Collecting and birding are derived explicitly from cultural ES as they are directly related to biological elements in the landscape. Biota taste positively correlated to a series of environmental 
Table 11. Standardized coefficients from ordinary least squares regressions of opinion on development on environmental tastes and socio-demographics $(* p<0.05, * * p<0.01$; only statistically significant results are reported).

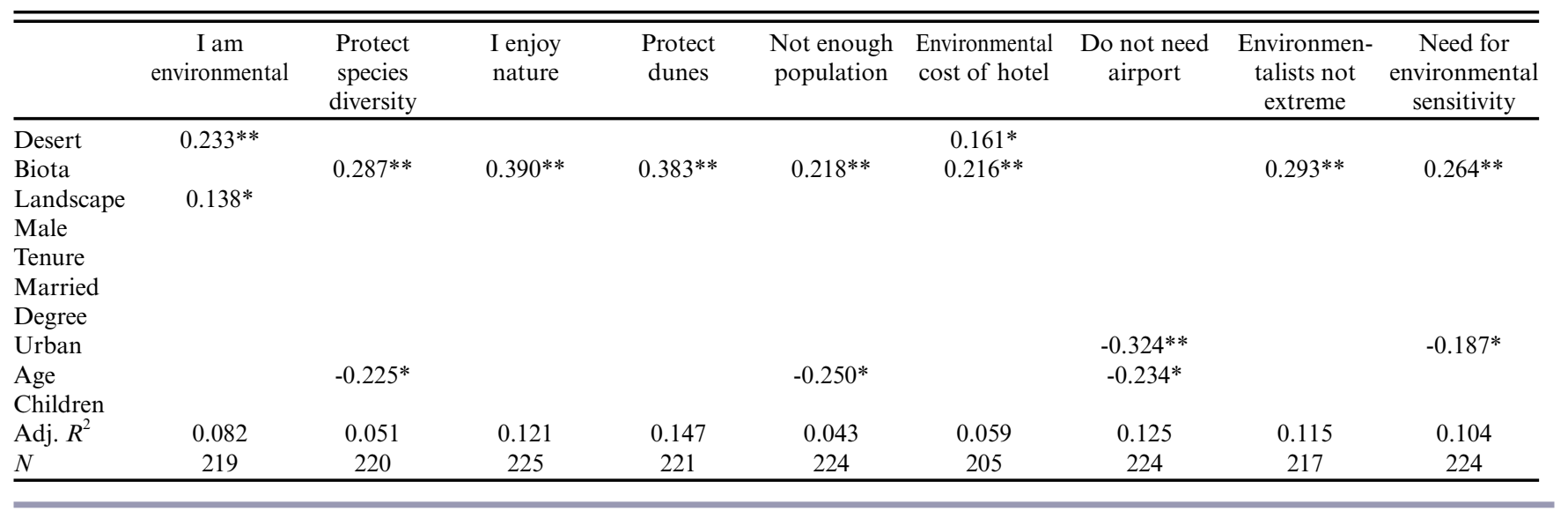

opinions, including the importance of protecting biological diversity and preventing habitat destruction. As such, this research may have identified an important factor in predicting environmental behaviors.

There are two methodological issues that challenge the research findings. First, ours was not a random sample of residents in the southern Arava Valley but rather a convenience sample. While we attempted to get as representative a sample as possible, there may be missing population sectors, particularly in the city of Eilat. Second, there are many geographical, cultural, climatic, and economic reasons why this particular population may be unique both in the Israeli context and the global context. We have conducted similar surveys in other regions of Israel and in other countries; preliminary results reflect a fairly consistent rank ordering of environmental tastes. We will use these results to better define the relationship between environmental tastes and behaviors and to test the effects of geographic setting in addition to the independent variables used here.

\section{Social valuation of ecosystem services: more than a number}

Social valuation of ES, as conducted here, can catalyze a discussion of ethical values, including a respect for biodiversity that transcends its economic role in human life and well-being (Rozzi et al. 2012). Stakeholders express particularly high affinity for environmental characteristics and claim strong environmental opinions. Preferences for environmental characteristics were extremely high, even as economic dependency on those same characteristics was often ranked low. Philosophers, deep ecologists, and others argue that concern for biodiversity should be intuitive and not connected to whether one can generate proof of its utility or economic value (Zimmerman 1994, Luck et al. 2012).

We suggest that social valuation of ES allows for inclusion of such ethical perspectives and encourages their acceptance as a legitimate part of civil discourse around the issue of ES. Further, social valuation allows for an understanding of humanenvironment interactions beyond the purely utilitarian (Raymond et al. 2013). Considered along with economic, biological, and health valuation, social valuation completes the necessarily broad spectrum of perspectives regarding the value of ecosystem services to humans (Martín-López et al. 2014). Obtaining each valuation depends on a particular disciplinary skill set drawn from the natural and/or social sciences, and hence the repeated call for both interdisciplinary research (diverse forms of expert knowledge) and transdisciplinary work (integration of local/ stakeholder knowledge [Haberl et al. 2006]). Each valuation approach reflects a particular perspective on the human experience, and each carries its own set of advantages and disadvantages with regard to accuracy and breadth. Together they provide a comprehensive picture of the complex relationship between humans and natural ecosystems, as is required for assessing the impact of human development on ES provision.

All of these conclusions support the claim that the integration of interdisciplinary scholars with competence in the social sciences into ES assessment is crucial (Chan et al. 2012, Martín-López et al. 2014). Although there has been a consistent rise in the amount of social research focusing on ES, as cited throughout this paper and additional work (Barthel et al. 2005, Andersson et al. 2007, Ernstson et al. 2010, Andersson et al. 2014), we suggest that social theory (as used, for example, in Barthel et al. 2010 with regard to social memory) can and should play a much stronger role in the future in understanding human values, motivations, and activities vis-à-vis ecosystems and their services.

Within the sociological and psychological literature, for example, there is a long and rich history of theoretical developments regarding how humans interact and value their natural environment, and what motivates them to utilize the environment or choose to actively work to protect it from degradation due to human activities, some of which are noted here. We encourage digging deeper into this literature in the service of ecosystem service assessment. By doing so, we can level the ES assessment playing field by raising the profile of socio-cultural valuation in policy-making and planning through the use of alternative measures of value that stakeholders attached to ES. Again, these measures complement traditional monetary valuation, which has been criticized on ethical and practical grounds (Kosoy and Corbera 2010, Spangenberg and Settele 2010, Rogers and Schmidt 2011, Turnhout et al. 2013). 
Our study has direct implications for the researchers and managers who are applying the concept of ES. Defining distinct dimensions of environmental tastes adds crucial nuance to our understanding of how different people value cultural ES differently. Differences in these taste dimensions may have a cascading impact on the way individuals perceive and benefit from other cultural ES (for instance, recreational activities) or how people perceive the economic importance of provisioning services. We are reminded that the general public does not fully understand the concept of ES or, more generally, human dependence on ecosystem integrity for providing ES (In Israel: Sagie et al. 2013, Orenstein and Groner 2014; elsewhere: UKNEA 2011). Because the term ES is not a common part of everyday language, its translation into measurable indicators is not clear cut. We propose that environmental tastes could provide such indicators.

As a "mission-oriented discipline" (Cowling et al. 2008), two of the goals of the ES conceptual framework are to educate the general public regarding the existential importance of biodiversity conservation to assure the long-term provision of ES, and to initiate policies that will meet this goal. Environmental tastes assist in learning about how groups of people perceive the presence and importance of ES and their contribution to their well-being. By strengthening our understanding of how people perceive and use their ecosystem via definition of environmental tastes, social analysis of ES can advance the normative goals of nature conservation policy and ecological education (Cowling et al. 2008, Menzel and Teng 2010).

In conclusion, our research suggests that a foundation for proenvironmental opinions and behaviors might be established by nurturing a taste for biota. As such, environmental educationparticularly that which focuses on forming a strong identification with biota - may play a key role in promoting understanding about human dependence on ecosystem integrity and generating pro-environmental opinions and behaviors. On the other hand, as landscape is consistently the most highly valued environmental characteristic, a holistic approach to ecosystem management, that which includes biotic and abiotic components of the ecosystem, should be considered.

${ }^{[1]}$ We note that the application of social theory to organize and explain our results occurred ex post facto to the formulation and distribution of the survey. That is, the survey was constructed and distributed with the intent of exploring attitudes and behaviors of the local population vis-à-vis ecosystem services, and not for the specific intent of testing the hypotheses noted here.

[2] Kibbutzim (kibbutz in singular) are Israeli cooperatives, pioneering communities in which property and income are shared among their members. When they were founded, agriculture was the primary economic activity of the kibbutz. However, in the past few decades, the economy of many kibbutzim has begun shifting, such that industry, services, and individual professional incomes have become prominent. Kibbutzim played an important, central role in Zionist settlement prior to the establishment of Israel in 1948, and continued to be central to peripheral, border settlement following the establishment of the state. Today, each kibbutz practices a different degree of cooperative living, some sharing property and income, while others are undergoing varying degrees of privatization.
${ }^{[3]}$ The most recent data at the municipality level are available only for 2008. In 2012, the Central Bureau of Statistics population estimate for the Eilot regional council had risen by $17 \%$, to 3500 , while the population of Eilat had risen only slightly (less than 1\%) to 47,700 (Central Bureau of Statistics of Israel 2014).

${ }^{[4]}$ We note that we do not, at this point, differentiate between the biological components of the ecosystem and the geological components (e.g., minerals), nor do we differentiate between ecosystem services and natural resources. We address this issue in the Discussion.

Responses to this article can be read online at: http://www.ecologyandsociety.org/issues/responses. $\mathrm{php} / 7545$

\section{Acknowledgments:}

We thank Hila Sagie, Inna Kaplan, and Danielle Cohen for their research assistance. We further thank Dr. Jan Dick, two anonymous reviewers, and the journal subject editor for their substantive and challenging comments and suggestions for strengthening the manuscript. Funding was provided through a trans-border cooperation grant from the Israel Ministry of Regional Cooperation to the Dead Sea and Arava Science Center.

\section{LITERATURE CITED}

Andersson, E., S. Barthel, and K. Ahrné. 2007. Measuring socialecological dynamics behind the generation of ecosystem services. Ecological Applications 17(5):1267-1278. http://dx.doi. org/10.1890/06-1116.1

Andersson, E., S. Barthel, S. Borgström, J. Colding, T. Elmqvist, C. Folke, and A. Gren. 2014. Reconnecting cities to the biosphere: stewardship of green infrastructure and urban ecosystem services. AMBIO 43(4):445-453. http://dx.doi.org/10.1007/s13280-014-0506y

Balmford, A., B. Fisher, R. Green, R. Naidoo, B. Strassburg, R. Kerry Turner, and A. S. L. Rodrigues. 2011. Bringing ecosystem services into the real world: an operational framework for assessing the economic consequences of losing wild nature. Environmental and Resource Economics 48(2):161-175. http://dx. doi.org/10.1007/s10640-010-9413-2

Barthel, S., J. Colding, T. Elmqvist, and C. Folke. 2005. History and local management of a biodiversity-rich, urban cultural landscape. Ecology and Society 10(2):10. [online] URL: http:// www.ecologyandsociety.org/vol10/iss2/art10/

Barthel, S., C. Folke, and J. Colding. 2010. Social-ecological memory in urban gardens-retaining the capacity for management of ecosystem services. Global Environmental Change 20(2):255-265. http://dx.doi.org/10.1016/j.gloenvcha.2010.01.001

Boldero, J. 1995. The prediction of household recycling of newspapers: the role of attitudes, intentions, and situational factors. Journal of Applied Social Psychology 25(5):440-462. http://dx.doi.org/10.1111/j.1559-1816.1995.tb01598.x

Bourdieu, P. 1984. A social critique of the judgement of taste. Harvard University Press, Cambridge, Massachusetts, USA. 
Bourdieu, P., and L. Wacquant. 1992. An invitation to reflexive sociology. Polity Press, Cambridge, UK.

Brown, G., J. M. Montag, and K. Lyon. 2011. Public participation GIS: a method for identifying ecosystem services. Society \& Natural Resources 25(7):633-651. http://dx.doi.org/10.1080/089$\underline{41920.2011 .621511}$

Bryan, B. A., C. M. Raymond, N. D. Crossman, and D. H. Macdonald. 2010. Targeting the management of ecosystem services based on social values: where, what, and how? Landscape and Urban Planning 97(2):111-122. http://dx.doi.org/10.1016/j. landurbplan.2010.05.002

Carfagna, L. B., E. A. Dubois, C. Fitzmaurice, M. Y. Ouimette, J. B. Schor, and M. Willis. 2014. An emerging eco-habitus: the reconfiguration of high cultural capital practices among ethical consumers. Journal of Consumer Culture 14:158-178. http://dx. doi.org/10.1177/1469540514526227

Central Bureau of Statistics of Israel. 2010. 2008 census. Jerusalem, Israel.

Central Bureau of Statistics of Israel. 2014. Statistical abstracts of Israel. Jerusalem, Israel.

Chan, K. M. A., A. D. Guerry, P. Balvanera, S. Klain, T. Satterfield, X. Basurto, et al. 2012. Where are cultural and social in ecosystem services? A framework for constructive engagement. BioScience 62(8):744-756. http://dx.doi.org/10.1525/bio.2012.62.8.7

Church, A., J. Burgess, and N. Ravenscroft. 2011. Cultural services. Pages 633-692 in UK National Ecosystem Assessment Technical Report. UNEP-WCMC, Cambridge, UK.

Costanza, R., R. de Groot, P. Sutton, S. van der Ploeg, S. J. Anderson, I. Kubiszewski, S. Farber, and R. K. Turner. 2014. Changes in the global value of ecosystem services. Global Environmental Change 26:152-158. http://dx.doi.org/10.1016/j. gloenvcha.2014.04.002

Cowling, R. M., B. Egoh, A. T. Knight, P. J. O'Farrell, B. Reyers, M. Rouget, D. J. Roux, A. Welz, and A. Wilhelm-Rechman. 2008. An operational model for mainstreaming ecosystem services for implementation. Proceedings of the National Academy of Sciences of the United States of America 105(28):9483-9488. http://dx.doi. org/10.1073/pnas.0706559105

Crossley, N. 2003. From reproduction to transformation: social movement fields and the radical habitus. Theory, Culture \& Society 20(6):43-68. http://dx.doi.org/10.1177/0263276403206003

Daniel, T. C., A. Muhar, A. Arnberger, O. Aznar, J. W. Boyd, K. M. A. Chan, et al. 2012. Contributions of cultural services to the ecosystem services agenda. Proceedings of the National Academy of Sciences of the United States of America 109(23):8812-8819. http://dx.doi.org/10.1073/pnas.1114773109

de Groot, J. I. M., and L. Steg. 2008. Value orientations to explain beliefs related to environmental significant behavior: how to measure egoistic, altruistic, and biospheric value orientations. Environment and Behavior 40(3):330-354. http://dx.doi. org/10.1177/0013916506297831

de Groot, R. S., R. Alkemade, L. C. Braat, L. Hein, and L. Willemen. 2010. Challenges in integrating the concept of ecosystem services and values in landscape planning, management and decision making. Ecological Complexity 7 (3):260-272. http://dx.doi.org/10.1016/j.ecocom.2009.10.006

de Groot, R. S., M. A. Wilson, and R. M. J. Boumans. 2002. A typology for the classification, description and valuation of ecosystem functions, goods and services. Ecological Economics 41(3):393-408. http://dx.doi.org/10.1016/s0921-8009(02)00089-7

Dempsey, J., and M. M. Robertson. 2012. Ecosystem services: tensions, impurities, and points of engagement within neoliberalism. Progress in Human Geography 36(6):758-779. http://dx.doi.org/10.1177/0309132512437076

Diamantopoulos, A., B. B. Schlegelmilch, R. R. Sinkovics, and G. M. Bohlen. 2003. Can socio-demographics still play a role in profiling green consumers? A review of the evidence and an empirical investigation. Journal of Business Research 56(6):465480. http://dx.doi.org/10.1016/S0148-2963(01)00241-7

Dietz, T., P. C. Stern, and G. A. Guagnano. 1998. Social Structural and social psychological bases of environmental concern. Environment \& Behavior 30(4):450-471. http://dx.doi. org/10.1177/001391659803000402

Duraiappah, A. K., and D. Rogers. 2011. The intergovernmental platform on biodiversity and ecosystem services: opportunities for the social sciences. Innovation: The European Journal of Social Science Research 24(3):217-224. http://dx.doi.org/10.1080/1351$\underline{1610.2011 .592052}$

Ehrlich, P. R., and H. A. Mooney. 1983. Extinction, substitution, and ecosystem services. BioScience 33(4):248-254. http://dx.doi. org/10.2307/1309037

Ernstson, H., S. E. van der Leeuw, C. J. Redman, D. J. Meffert, G. Davis, C. Alfsen, and T. Elmqvist. 2010. Urban transitions: on urban resilience and human-dominated ecosystems. AMBIO 39 (8):531-545. http://dx.doi.org/10.1007/s13280-010-0081-9

Fagerholm, N., N. Käyhkö, F. Ndumbaro, and M. Khamis. 2012. Community stakeholders' knowledge in landscape assessments0mapping indicators for landscape services. Ecological Indicators 18:421-433. http://dx.doi.org/10.1016/j.ecolind.2011.12.004

Fisher, B., R. K. Turner, and P. Morling. 2009. Defining and classifying ecosystem services for decision making. Ecological Economics 68(3):643-653. http://dx.doi.org/10.1016/j. ecolecon.2008.09.014

Gee, K., and B. Burkhard. 2010. Cultural ecosystem services in the context of offshore wind farming: a case study from the west coast of Schleswig-Holstein. Ecological Complexity 7(3):349358. http://dx.doi.org/10.1016/j.ecocom.2010.02.008

Gray, M. 2011. Other nature: geodiversity and geosystem services. Environmental Conservation 38(3):271-274. http://dx.doi.org/10.1017/ s0376892911000117

Guagnano, G. A., P. C. Stern, and T. Dietz. 1995. Influences on attitude-behavior relationships: a natural experiment with curbside recycling. Environment \& Behavior 27(5):699-718. http:// dx.doi.org/10.1177/0013916595275005

Haberl, H., V. Winiwarter, K. Andersson, R. U. Ayres, C. Boone, A. Castillo, et al. 2006. From LTER to LTSER: conceptualizing 
the socioeconomic dimension of long-term socioecological research. Ecology and Society 11(2):13. [online] URL: http://www. ecologyandsociety.org/vol11/iss2/art13/

Haluza-DeLay, R. 2008. A theory of practice for social movements: environmentalism and ecological habitus. Mobilization: The International Quarterly 13(2):205-218.

Horton, D. 2003. Green distinctions: the performance of identity among environmental activists. Sociological Review 51(s2):63-77. http://dx.doi.org/10.1111/j.1467-954x.2004.00451.x

Jax, K. 2010. Ecosystem functioning. Cambridge University Press, Cambridge, UK. http://dx.doi.org/10.1017/CBO9780511781216

Jones, R. E., and R. E. Dunlap. 1992. The social bases of environmental concern: have they changed over time? Rural Sociology 57(1):28-47. http://dx.doi.org/10.1111/j.1549-0831.1992. $\underline{\mathrm{tb} 00455 . \mathrm{x}}$

Kosoy, N., and E. Corbera. 2010. Payments for ecosystem services as commodity fetishism. Ecological Economics 69(6):1228-1236. http://dx.doi.org/10.1016/j.ecolecon.2009.11.002

Luck, G. W., K. M. A. Chan, U. Eser, E. Gómez-Baggethun, B. Matzdorf, B. Norton, and M. B. Potschin. 2012. Ethical considerations in on-ground applications of the ecosystem services concept. BioScience 62(12):1020-1029. http://dx.doi. org/10.1525/bio.2012.62.12.4

Martín-López, B., E. Gómez-Baggethun, M. García-Llorente, and C. Montes. 2014. Trade-offs across value-domains in ecosystem services assessment. Ecological Indicators 37(Part A):220-228. http://dx.doi.org/10.1016/j.ecolind.2013.03.003

Maynard, S., D. James, and A. Davidson. 2010. The development of an ecosystem services framework for south east Queensland. Environmental Management 45(5):881-895. http://dx.doi.org/10.1007/ $\underline{\mathrm{s} 00267-010-9428-\mathrm{Z}}$

Menzel, S., and J. Teng. 2010. Ecosystem services as a stakeholderdriven concept for conservation science. Conservation Biology 24 (3):907-909. http://dx.doi.org/10.1111/j.1523-1739.2009.01347. $\underline{\mathrm{X}}$

Milcu, A. I., J. Hanspach, D. Abson, and J. Fischer. 2013. Cultural ecosystem services: a literature review and prospects for future research. Ecology and Society 18(3):44. http://dx.doi.org/10.5751/ es-05790-180344

Orenstein, D. E., and E. Groner. 2014. In the eye of the stakeholder: changes in perceptions of ecosystem services across an international border. Ecosystem Services 8:185-196. http://dx. doi.org/10.1016/j.ecoser.2014.04.004

Orenstein, D. E., L. Jiang, and S. P. Hamburg. 2011. An elephant in the planning room: political demography and its influence on sustainable land-use planning in drylands. Journal of Arid Environments 75(6):596-611. http://dx.doi.org/10.1016/j. jaridenv.2011.01.008

Palacios-Agundez, I., B. Fernández de Manuel, G. RodríguezLoinaz, L. Peña, I. Ametzaga-Arregi, J. Alday, I. CasadoArzuaga, I. Madariaga, X. Arana, and M. Onaindia. 2014. Integrating stakeholders' demands and scientific knowledge on ecosystem services in landscape planning. Landscape Ecology 29:1423-14331. http://dx.doi.org/10.1007/s10980-014-9994-1
Paracchini, M. L., G. Zulian, L. Kopperoinen, J. Maes, J. P. Schägner, M. Termansen, M. Zandersen, M. Perez-Soba, P. A. Scholefield, and G. Bidoglio. 2014. Mapping cultural ecosystem services: a framework to assess the potential for outdoor recreation across the EU. Ecological Indicators 45:371-385. http:// dx.doi.org/10.1016/j.ecolind.2014.04.018

Raymond, C. M., I. Fazey, M. S. Reed, L. C. Stringer, G. M. Robinson, and A. C. Evely. 2010. Integrating local and scientific knowledge for environmental management. Journal of Environmental Management 91(8):1766-1777. http://dx.doi. org/10.1016/j.jenvman.2010.03.023

Raymond, C. M., G. G. Singh, K. Benessaiah, J. R. Bernhardt, J. Levine, H. Nelson, N. J. Turner, B. Norton, J. Tam, and K. M. A. Chan. 2013. Ecosystem services and beyond: using multiple metaphors to understand human-environment relationships. BioScience 63(7):536-546. http://dx.doi.org/10.1525/bio.2013.63.7.7

Reid, W. V., H. A. Mooney, A. Cropper, D. Capistrano, S. R. Carpenter, K. Chopra, et al. 2005. Ecosystems and human wellbeing: synthesis. Page 155 in J. Sarukhan and A. Whyte, editors. Millennium ecosystem assessment. World Resources Institute, Washington, D.C., USA.

Rogers, D., and F. Schmidt. 2011. Social dimensions of ecosystem services. IASS, Potsdam, Germany.

Rozzi, R., J. J. Armesto, J. R. Gutiérrez, F. Massardo, G. E. Likens, C. B. Anderson, et al. 2012. Integrating ecology and environmental ethics: Earth stewardship in the southern end of the Americas. BioScience 62(3):226-236. http://dx.doi.org/10.1525/ bio.2012.62.3.4

Russell, R., A. D. Guerry, P. Balvanera, R. K. Gould, X. Basurto, K. M. A. Chan, S. Klain, J. Levine, and J. Tam. 2013. Humans and nature: how knowing and experiencing nature affect wellbeing. Annual Review of Environment and Resources 38(1):473502. http://dx.doi.org/10.1146/annurev-environ-012312-110838

Sagie, H., A. Morris, Y. Rofè, D. E. Orenstein, and E. Groner. 2013. Cross-cultural perceptions of ecosystem services: a social inquiry on both sides of the Israeli-Jordanian border of the southern Arava Valley desert. Journal of Arid Environments 97:38-48. http://dx.doi.org/10.1016/j.jaridenv.2013.05.007

Sela-Sheffy, R. 2011. Settlers, environmentalism and identity: western Galilee, 1949-1965. Pages 49-60 in D. Roel, editor. Cultural heritage and identity politics. Wageningen UR/The Silk Road Research Foundation, Wageningen, Netherlands.

Singh, S. J., H. Haberl, M. Chertow, M. Mirtl, and M. Schmid. 2013. Introduction. Pages 1-26 in S. J. Singh, H. Haberl, M. Chertow, M. Mirtl, and M. Schmid, editors. Long term socioecological research. Springer, Dordrecht, Netherlands. http://dx. doi.org/10.1007/978-94-007-1177-8 1

Sodhi, N., T. Lee, C. Sekercioglu, E. Webb, D. Prawiradilaga, D. Lohman, N. E. Pierce, A. C. Diesmos, M. Rao, and P. R. Ehrlich. 2010. Local people value environmental services provided by forested parks. Biodiversity and Conservation 19(4):1175-1188. http://dx.doi.org/10.1007/s10531-009-9745-9

Spangenberg, J. H., C. Görg, D. T. Truong, V. Tekken, J. V. Bustamante, and J. Settele. 2014. Provision of ecosystem services is determined by human agency, not ecosystem functions. Four 
case studies. International Journal of Biodiversity Science, Ecosystem Services \& Management 10(1):40-53. http://dx.doi. org/10.1080/21513732.2014.884166

Spangenberg, J. H., and J. Settele. 2010. Precisely incorrect? Monetising the value of ecosystem services. Ecological Complexity 7(3):327-337. http://dx.doi.org/10.1016/j.ecocom.2010.04.007

Stern, P. C. 2000. New environmental theories: toward a coherent theory of environmentally significant behavior. Journal of Social Issues 56(3):407-424. http://dx.doi.org/10.1111/0022-4537.00175

Tengberg, A., S. Fredholm, I. Eliasson, I. Knez, K. Saltzman, and O. Wetterberg. 2012. Cultural ecosystem services provided by landscapes: assessment of heritage values and identity. Ecosystem Services 2:14-26. http://dx.doi.org/10.1016/j.ecoser.2012.07.006

Termorshuizen, J., and P. Opdam. 2009. Landscape services as a bridge between landscape ecology and sustainable development. Landscape Ecology 24(8):1037-1052. http://dx.doi.org/10.1007/ $\underline{\mathrm{s} 10980-008-9314-8}$

Turnhout, E., C. Waterton, K. Neves, and M. Buizer. 2013. Rethinking biodiversity: from goods and services to "living with". Conservation Letters 6:154-161. http://dx.doi.org/10.1111/ j.1755-263X.2012.00307.X

UK-NEA. 2011. The UK National Ecosystem Assessment: synthesis of the key findings. UNEP-WCMC, Cambridge, UK.

Zimmerman, M. E. 1994. Contesting Earth's future. University of California Press, Berkeley, California, USA. 